\title{
Rainfall shocks, cognitive development and educational attainment among adolescents in a drought-prone region in Kenya
}

\author{
Laura Nübler, ${ }^{1}$ Karen Austrian, ${ }^{2}$ John A. Maluccio, ${ }^{3 *}$ (D) and Jessie Pinchoff ${ }^{4}$ \\ ${ }^{1}$ Department of Empirical Health Economics, Technical University of Berlin, Berlin, Germany; \\ ${ }^{2}$ Population Council, Nairobi, Kenya; ${ }^{3}$ Middlebury College, Middlebury, VT, USA and ${ }^{4}$ Population \\ Council, New York, NY, USA \\ ${ }^{*}$ Corresponding author. E-mail: jmalucci@middlebury.edu
}

(Submitted 20 March 2019; revised 10 February 2020, 17 June 2020; accepted 06 August 2020; first published online 3 November 2020)

\begin{abstract}
There is growing evidence that early life conditions are important for outcomes during adolescence, including cognitive development and education. Economic conditions at the time children enter school are also important. We examine these relationships for young adolescents living in a low-income drought-prone pastoral setting in Kenya using historical rainfall patterns captured by remote sensing as exogenous shocks. Past rainfall shocks measured as deviations from local long-term averages have substantial negative effects on the cognitive development and educational achievement of girls. Results for the effects of rainfall shocks on grades attained, available for both girls and boys, support that finding. Consideration of additional outcomes suggests the effects of rainfall shocks on education are due to multiple underlying mechanisms including persistent effects on the health of children and the wealth of their households, underscoring the potential value of contemporaneous program and policy responses to such shocks.
\end{abstract}

Keywords: adolescents; cognitive development; drought; Hunger Safety Net Program; Kenya; schooling; unconditional cash transfer

JEL classification: I15; I25; Q54

\section{Introduction}

Rainfall shocks pose substantial challenges to economic wellbeing in settings where the dominant livelihoods are based on agriculture and livestock (Paxson, 1992; Miguel et al., 2004). Throughout the African continent, expected changes to precipitation patterns resulting from climate change will likely alter agricultural production, increasing the frequency of shocks in many areas (IPCC, 2014). A challenge for areas relying on rain-fed agriculture, changing rainfall patterns also threaten areas where livestock-based pastoral livelihoods dominate. Low rainfall and drought lead to a decline in water availability 
and forage, which affect livestock health and reduces prices (Opiyo et al., 2015). Pastoralists may be even more severely affected than farmers because recovery from shocks, including having to rebuild herds, can take several years (Kimiti et al., 2018). Together, these factors make improved understanding of the persistent effects of rainfall shocks and underlying mechanisms a priority.

To provide relevant evidence, we examine human capital outcomes for adolescents in a semi-arid pastoralist setting. Following previous literature (e.g., Burke et al., 2015), we treat deviations from local long-term average rainfall - proxy measures for droughtlike conditions - as exogenous economic shocks and estimate their reduced form causal effects on cognitive and educational outcomes. Because the outcomes reflect cumulative investments over many years, and shocks at different points in the life of a child potentially have different short- and long-term effects, the analysis incorporates a history of shocks from birth up to the typical ages for starting primary school. We then employ the same research design to explore possible mechanisms underlying the persistence of the effects of shocks experienced earlier in life.

Using detailed survey data on young adolescent girls, we find that rainfall shocks during early childhood and near the ages when children typically start school substantially lowered the probability that they had ever enrolled in school, and reduced completed schooling by nearly a full grade. The same shocks also reduced achievement in basic reading and math. Only shocks occurring in early life, however, significantly reduced cognitive skills. Separate examination of completed grades for both girls and boys using census data from a regional safety net program broadly confirms the findings for early life and later shocks for both genders. Examining potential mechanisms, we find evidence that shocks likely operate both through persistent effects on the girls themselves, reflected in their schooling attitudes and expectations, and self-reported health assessments, as well as through persistent effects on the wealth of their households.

The paper provides new evidence on whether and at what ages rainfall shocks influence different cognitive and educational outcomes in a pastoralist setting, a context for which there is little related research. We contribute to the literature by exploring the mechanisms underlying those effects for young adolescent girls at an important juncture in their development - when many are dropping out of school and beginning their productive and reproductive lives.

\section{Economic shocks and individual outcomes}

Substantial literature documents the importance of rainfall and weather patterns for economic outcomes in low-income settings, including in much of sub-Saharan Africa (Dercon et al., 2005; Björkman-Nyqvist, 2013). Most commonly the link is explained by the critical role of rainfall in crop agriculture and the role of agriculture in rural livelihoods in the region (Davis et al., 2010). Links through civil conflict resulting from economic stress have also been investigated (Miguel et al., 2004). Additionally, there are aspects of disease transmission related to weather that can influence individual health outcomes (Rabassa et al., 2014; Berazneva and Byker, 2017). In settings where pastoralism rather than crop agriculture is the main economic activity, such as I semi-arid Wajir County, Kenya, rainfall patterns play a vital role through similar mechanisms (Fafchamps et al., 1998; Kazianga and Udry, 2006; ASDSP, 2014; Maystadt and Ecker, 2014).

Building on the crucial role of rainfall, investigators use exogenous rainfall measures to examine the causal effect of economically meaningful shocks during childhood on contemporaneous or later human capital outcomes. In addition to exogenous variation, 
a key element of the research design for this research is that historical rainfall measures provide shock indicators at different points throughout the life of the child. In such research, the correlation observed between rainfall deviations and the outcome is interpreted to be caused by the indirect effects of the rainfall shocks operating through economic or other conditions (Burke et al., 2015). Research has examined human capital outcomes measured in childhood (typically anthropometrics), adolescence (schooling, achievement and cognition), and adulthood (completed schooling and marriage, fertility and labor market outcomes) (Currie and Vogl, 2012; Frankenberg and Thomas, 2018). Studies typically consider shocks in early life (e.g., the first two or three years) or shocks during later childhood or school-age years, but only a few incorporate both periods into a single framework as done in this paper.

Research examining rainfall or other shocks in early life demonstrates that they can have negative consequences on physical and cognitive outcomes during this critical developmental period (Glewwe and King, 2001; Hoddinott and Kinsey, 2001; Grace et al., 2012; Rabassa et al., 2014). Moreover, effects can persist, translating into longerterm impacts in adolescence and adulthood (Alderman et al., 2006; Maccini and Yang, 2009; Currie and Vogl, 2012; Thai and Falaris, 2014; Dinkelman, 2017). Leight et al. (2015) provide evidence of the effects of early life shocks at different stages in life using panel data from China; they find negative effects of early life shocks on early childhood anthropometry and on later primary school age cognitive skills. Their findings also indicate partial 'catch-up' for those experiencing early life shocks, demonstrating some recovery, possibly the result of compensatory behaviors and investments within households. Akresh et al. (2012) use early childhood shocks in Burkina Faso as instrumental variables for ability in relations modeling adolescent schooling and find evidence that the shocks reduce human capital directly through reductions in ability, and indirectly through consequent differential investments across siblings. The studies underscore how observed effects of past shocks capture the net cumulative effect of the initial shocks as well as subsequent influences and behaviors undertaken in response.

Research on shocks during later childhood up to early school ages points to the potential importance of that period as well (Beegle et al., 2006). Moreover, effects may differ for girls who in some settings face different social, economic and cultural barriers to their development and educational attainment than boys. Gender expectations, low prioritization of female education, early marriage and childbearing can all limit adolescent development, and the influence of many of these factors may be exacerbated during periods of low rainfall or drought. Björkman-Nyqvist (2013) finds that shocks had more detrimental effects on educational outcomes of school-age girls than boys in Uganda. Shocks during childhood may also lower the age at which girls marry in settings like Wajir where it is common for the groom and his family to pay a bride price; such early marriage might even be a mechanism for household consumption smoothing (Corno et al., 2017).

A smaller set of studies examines shocks both in early life and in subsequent childhood periods in a single framework. In addition to the mechanisms described above, rainfall shocks may operate differently at different periods of individuals' lives because of the timing of physical development and also because, in settings where low rainfall affects wages, there is another pathway to human capital investment through changes in the opportunity cost of time for children. Shah and Steinberg (2017) demonstrate in India that positive rainfall shocks in early life improved adult educational outcomes but positive shocks during school-age years lowered them. They argue that the latter reduction 
results from pulling students out of school when there are positive productivity shocks and associated higher wages.

In all analyses using historical shocks, observed outcomes capture the cumulative effect of: (1) the historical pattern of the shocks themselves, (2) previous anticipatory behaviors, and (3) any subsequent actions and investments undertaken by families. The latter, for example, include the investments highlighted by Leight et al. (2015) and Akresh et al. (2012). Frankenberg and Thomas (2018) find that subsequent investments undertaken by families have the potential to substantially limit the longer-term effects of large shocks in Indonesia; they also argue that such behavioral responses will likely vary by context, making it difficult to reach general conclusions about the effect of shocks in different settings. Last, in addition to individual- or household-level factors, the outcomes are also conditioned by the surrounding program and policy environment (Frankenberg and Thomas, 2018).

\section{Wajir County context and data}

Situated in northeastern Kenya on the Somali border, Wajir County is a sparsely populated region with a predominantly Muslim population. It has about 800,000 residents and on average only 14 persons per square kilometer $(\mathrm{km})$, though most residents are clustered together and live in small concentrated settlements or towns. In 2005 the extreme poverty rate was 58 per cent, and overall poverty was 84 per cent (Merttens, 2018). The region has experienced insecurity in recent years related to instability in Somalia, especially near the international border (ASDSP, 2014).

Wajir has a hot, semi-arid desert climate and the primary economic activity is pastoralism. Only a few thousand of its 57,000 square $\mathrm{km}$ are arable, and only a fraction of that cultivated. Consequently, livestock and related products dominate the local economy. In 2013 livestock products were valued at nearly 50 times crop production (ASDSP, 2014).

The pastoral-based livelihoods of the population make it sensitive to low rainfall and drought conditions. These conditions can have substantial effects on livestock prices and economic wellbeing (Kazianga and Udry, 2006). Additionally, during drought family members may need to travel farther, or even relocate altogether, to find suitable watering sites or pasture for their herds (MoALF, 2017; Merttens, 2018). These factors make Wajir a particularly relevant setting for examining some of the longer-term consequences of local rainfall shocks.

The pastoral-based livelihoods in Wajir also have implications for educational outcomes in the county. The ethnolinguistic groups in Kenya that commonly practice pastoralism, the Somali and Maasai, are the least likely to send their children to school, which is related to factors including cultural norms, language and opportunity costs of time (Vimefall et al., 2017). Consistent with this pattern, the largely Somali Wajir County has the lowest adult literacy rate (26 per cent) and the lowest average female education in the country (KNBS, 2015). Median grades completed are zero for adult women and 4.7 for men (KNBS, 2015). Notably, the educational gender gap in Wajir is one of the highest in the country. Low levels of female education are accompanied by early marriage and high fertility; the median age at first marriage was 18 and the total fertility rate 7, the highest in Kenya (KNBS, 2015).

We combined remotely sensed, local historical rainfall data with: (1) individual-level data from a 2015 survey carried out in Wajir for the Adolescent Girls Initiative-Kenya (AGI-K) and, separately, (2) individual-level data from a 2013 census of Wajir carried out 
(a)

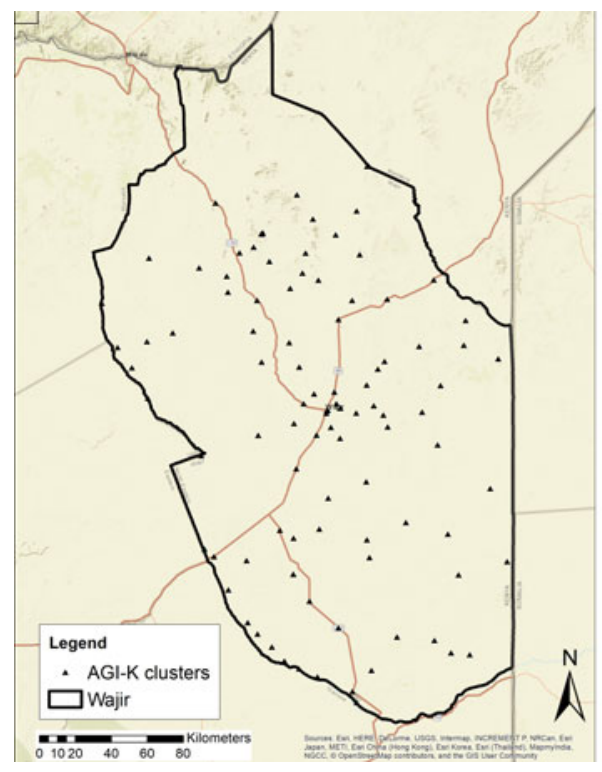

(b)

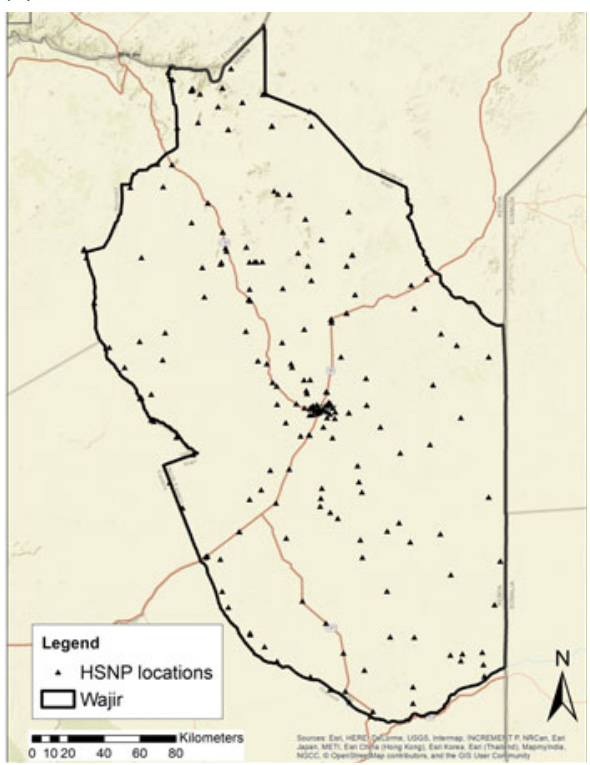

Figure 1. (a) AGI-K 2015 survey villages, (b) HSNP census survey locations.

by the Hunger Safety Net Programme (HSNP). Because communities in Wajir depend on rainfall for agricultural and pastoral livelihoods, we use rainfall anomalies to capture lower than expected precipitation.

\subsection{Adolescent Girls Initiative-Kenya (AGI-K): 2015 baseline survey}

The first data source is the 2015 baseline survey collected for the AGI-K study of girls ages 11-14. AGI-K identified 80 rural villages with a primary school in areas of Wajir County except for Wajir North (figure 1a), which was excluded because for security reasons the implementing partner did not operate there. In villages with fewer than 40 households with eligible girls, all households and girls ages 11-14 were interviewed. In larger villages, 40 households were randomly selected and within each one girl aged 11-14 was interviewed (Austrian et al., 2016).

Female enumerators implemented a comprehensive survey at both the household and individual girl levels. The household survey was conducted with the household head or guardian adult in the language of their choice and included household characteristics, assets and parental attitudes toward education. The individual girl level survey collected information on schooling history and educational attainment, among other things. We construct binary indicators of ever enrolled (whether an individual had ever enrolled in any level of primary schooling), and whether the individual had ever enrolled by age eight. We characterize schooling grade progress by the total number of completed grades.

Enumerators also administered three education-related tests in the home, covering literacy in the two languages used in public school instruction, mathematics and nonverbal cognitive skills. To avoid selection bias since nearly 25 per cent of girls were not enrolled in school, all girls regardless of schooling status took the test. The literacy test 
assessed the ability to read aloud completely without error two sentences in Swahili and two sentences in English. The mathematics test assessed numeracy and facility with basic arithmetic including 26 questions based on the Kenyan grade 2 level mathematics curriculum using the Kenya National Learning Assessment tool (UWEZO, 2014). The third assessment was the Raven Coloured Progressive Matrices test, a nonverbal multiple-choice assessment of cognitive skills in which the respondent identifies the missing element completing a pattern (Raven et al., 1984). Rather than directly assessing schooling-related achievement, the Raven test measures the ability to make sense out of confusing or complex data and perceive new patterns and relationships.

The AGI-K survey also collected information on schooling attitudes and expectations for the girls which enables exploration of underlying mechanisms. Girls were asked about the importance they ascribed to schooling and how confident they felt about being able to attain their schooling objectives. Girls also provided self-reported health assessments. And, although there was no comprehensive expenditure or income module at the household level, the survey collected an array of indicators related to household economic wellbeing or wealth. The final sample size for the individual AGI-K girl-level survey was 2,147 . Some girls resided in the same household, so at the household level the final sample size was 2,030 .

\subsection{Hunger and Safety Net Programme (HSNP): 2013 census}

HSNP is an unconditional government cash transfer program targeted to poor households and operating since 2009 in four counties in northern Kenya including Wajir. The overall program objectives are to reduce poverty, food insecurity and malnutrition by providing transfers of $\sim$ US $\$ 20-30$ every other month. More specifically, it aims to promote asset accumulation as well as to protect assets including livestock during economically challenging periods such as drought conditions. In addition to those main outcomes, it was hypothesized that HSNP might improve various indicators including schooling and health and strengthen resilience to shocks. The program was rolled out to non-randomly selected clusters between 2009 and 2013, reaching 20,000 households (or one-eighth of the population) in Wajir (Merttens, 2018).

In preparation for expansion in the second phase, HSNP carried out a census of program areas in 2013, collecting demographic and educational information for all household members, along with some household level characteristics and assets. A key objective of the census was to measure characteristics used for calculating a proxy means test score. In conjunction with a community-based wealth ranking exercise, the proxy means test scores determined household-level program eligibility (Merttens, 2018). The 2013 HSNP census includes 93,418 individuals ages 9-14 (42,157 girls and 51,261 boys) living in 48,983 different households across 274 locations of Wajir County (figure 1b). Although the HSNP census data only provide school enrollment and grades completed, the advantages of this data source compared to the AGI-K survey sample are that it enables assessment of both girls and boys and that it covers a larger proportion of the county. In addition, the large sample size increases power.

\subsection{Rainfall data and construction of rainfall shocks}

To construct historical rainfall measures we use Climate Hazards Group InfraRed Precipitation with Station data (CHIRPS), satellite-based high resolution gridded data spanning latitudes $50^{\circ} \mathrm{S}$ to $50^{\circ} \mathrm{N}$ that capture daily and monthly precipitation from 1981 
Z-Score Maps for four time periods, Wajir

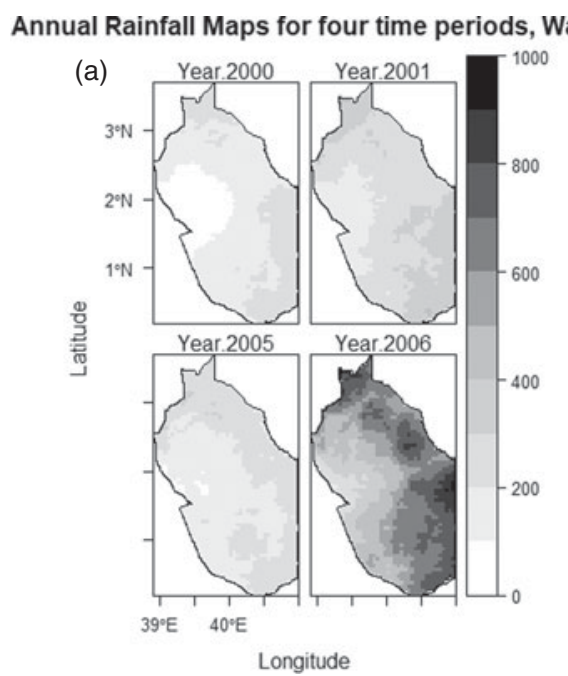

(a) (b)

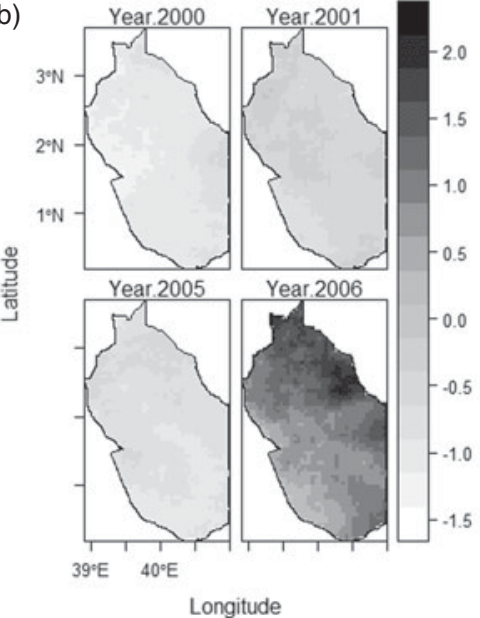

Figure 2. Wajir County rainfall (in 2000, 2001, 2005, 2006). (a) Average annual rainfall in $\mathrm{mm}$, (b) Z-score deviations from historical average rainfall.

to the present (Funk et al., 2015). We used the aggregated data consisting of monthly raster files, each containing a grid with $0.05 \times 0.05$ degree spatial resolution. In Kenya, each data point (or pixel) represents an approximate $5 \mathrm{~km} \times 5 \mathrm{~km}$ square. Using the global positioning system (GPS) coordinates for each location where sample individuals lived, we imputed average monthly rainfall for a $10 \mathrm{~km}$ radius buffer, averaging the rainfall values across grid cells that overlaid the buffer. The $10 \mathrm{~km}$ buffer is intended to approximate the area a pastoralist would typically range with their herd from a home base, though $5 \mathrm{~km}$ buffers yielded similar results. The rainfall data are available starting in 1981, nearly 20 years before the birth of the oldest children surveyed. Using the monthly measures, we constructed historical long-term averages and standard deviations (SD) from 1981-1999 for each location and then used the measures to construct standardized z-scores for each location in each year after 1999. Standardization at the local $10 \mathrm{~km}$ radius area, rather than a larger one, controls for differences in local average rainfall. Because individuals living in areas that have historically low average rainfall may employ anticipatory strategies in response, typical low levels of rainfall they experience are not exogenous shocks in the way that deviations from local averages can be. The procedure yields annual measures of the $\mathrm{z}$-score for every location where sample individuals lived each year from 2000-2015.

In the next step, we use the z-scores to construct a binary indicator for whether the location experienced a local rainfall shock each year. To ensure they are substantial, we define a shock as average annual precipitation one or more SD below the local historical average. Online appendix table A1 presents average $\mathrm{z}$-scores and the prevalence of local rainfall shocks across locations by year from 2000 through 2015 for each sample. There is substantial variation in rainfall deviations over time, reflected in the differences in average $\mathrm{z}$-scores across years, and minimal correlation over time. In 11 out of 16 years, average $\mathrm{z}$-scores were negative. One or more SD rainfall shocks are uncommon in recent years in Wajir and concentrated in only two calendar years: 2000 and 2005. In all other years, less than 5 per cent of the study locations experienced shocks. 
Table 1. Rainfall shocks in Wajir County, by location and age

\begin{tabular}{lcc} 
& AGl-K clusters & HSNP census locations \\
\cline { 2 - 3 } Age & $\begin{array}{c}\text { \% of children with z-score }<-1 \\
\text { when age }[. .]\end{array}$ & $\begin{array}{c}\text { \% of children with z-score }<-1 \\
\text { when age [..] }\end{array}$ \\
\hline 0 (first year of life) & 3.9 & 13.5 \\
\hline 1 & 14.2 & 8.1 \\
\hline 2 & 17.0 & 16.5 \\
\hline 3 & 12.9 & 6.1 \\
\hline 4 & 9.4 & 20.1 \\
\hline 5 & 1.1 & 8.7 \\
\hline 6 & 1.2 & 0.9 \\
\hline 7 & 0.7 & 0.5 \\
\hline 8 & 1.0 & 1.2 \\
\hline 9 & 1.1 & 0.9 \\
\hline $\mathrm{N}$ & 2,147 & 93,418 \\
\hline
\end{tabular}

Notes: Percentage of individuals experiencing rainfall shock at each age, based on calendar year shocks reported in online appendix table A1.

Calendar year shocks, however, are experienced by children living in the same location, or even the same household, at different ages. We map average annual rainfall patterns for these years in figure 2a. In 2000, low rainfall was widespread in Wajir and affected most locations throughout the county (including more than 90 per cent of the study locations) whereas in 2005 low rainfall affected only about half of the locations. The latter year underscores the variation across different locations in Wajir County. A comparison with the subsequent calendar years 2001 and 2006 shows the variation over time. Rainfall shocks in this paper are not measured by overall rainfall, but rather by deviations from local historical averages. In figure $2 \mathrm{~b}$ we present the $\mathrm{z}$-score deviations from the historical averages for the same calendar years (with lighter areas representing more negative $\mathrm{z}$-scores), demonstrating there is similarly substantial variation in $\mathrm{z}$-scores across time and space.

The final step uses age and resident location to link each sample individual to the rainfall shock data so that for every individual we have indicators for whether they experienced a rainfall shock in their resident location in each year of their lives. In table 1 we summarize exposure to rainfall shocks by age for all children in each sample, beginning with the year the child was born. Because the most recent year with substantial rainfall shocks was 2005, the percentage of children in the sample with rainfall shocks declines with their age and is rare at the older ages.

\section{Methodology}

Drawing from the literature, we theorize that rainfall shocks affect adolescent education primarily through their effects on household-level resources and the value of activities often done by children such as herding. These effects can differ at each stage of child development. 
Negative economic shocks to household income or wealth during early childhood can limit household resources available for nutrition, health and care, directly affecting early life physical and cognitive development. Offsetting behavioral responses (such as selling assets in the short term) may not fully prevent reductions in child investments and also may result in persistently reduced household resources. Consequently, shocks during early years can also influence later life outcomes, either through persistently reduced household resources available to invest in education during school ages or through persistent negative effects on the young child's physical or cognitive preparedness to advance in school. There might also be persistent effects on schooling attitudes and expectations (Wydick et al., 2013).

Similarly, rainfall shocks when children are older can reduce household resources available for child investment at that point as well. Later shocks might also change the opportunity cost (or value) of time of the now older children who often assist in carrying out household chores and herding, a particularly important activity for children in the Wajir context. In the extreme, when herding animals locally is no longer possible, children might need to travel long distances with the herd, making it infeasible for them to attend school. In such instances, child schooling might be interrupted because of short-term economic necessity.

A final relevant aspect of mechanisms evident in the literature is the potential for gendered effects resulting from possible differences in physical development, societal attitudes, initial schooling differences, economic returns and the willingness of parents to invest in children. Some literature suggests that impacts of shocks might be larger for girls than for boys. When asked about the importance of investments in child schooling, nearly one-third of parents in the AGI-K survey sample indicated they would prioritize male over female education when facing financial constraints, suggesting investments in females would be more sensitive to negative shocks. In Wajir, evidence from this study indicates girls are commonly responsible for herding so that rainfall shocks can affect their opportunity costs. Given the survey design, in this paper we primarily analyze girls and are unable to comprehensively assess gender differentials.

Turning to the econometric specifications, we first estimate a reduced form crosssectional econometric model that incorporates multiple past annual rainfall shocks from birth through early primary school ages as exogenous determinants of educational outcomes. The base model includes rainfall shocks at each age:

$$
y_{i j}=\beta_{0}+\sum_{a=a_{0}}^{T} \delta_{a} S_{i j, a}+\boldsymbol{X}_{i j} \boldsymbol{\beta}_{1}+u_{i j}
$$

where $y_{i j}$ is the outcome for child $i$ in resident location $j . S_{i j, a}$ is a binary indicator for whether there was a rainfall shock in child $i$ s location $j$ when she was age $a$, with age ranging from $a_{0}$ to $T$. For the analysis using the AGI-K survey sample, $a$ ranges from 0 (the first year of life) to 7 , after which few girls experienced shocks (table 1). For a 14 -year-old at the time of the survey in 2015 and therefore born in $2001, S_{i j, 0}$ is the binary rainfall shock indicator for her location $j$ in 2001, when she was $a=0$ years old; $S_{i j, 1}$ is the rainfall shock indicator for when she was $a=1$ year old in 2002; and so on up to $S_{i j, 7}$ for when she was $a=7$ years old in 2008. The rainfall shock indicators for children of different ages when interviewed in 2015 are constructed similarly. Accurate measurement 
of both age and resident location are important for the analysis. ${ }^{1}$ The negative rainfall shocks also may have influenced mortality, resulting in a selective sample with healthier individuals more likely to have survived. Both possible mismeasurement and selective mortality would likely lead to attenuation bias in the estimation of (the negative) shock parameters, making them conservative. The set of controls in vector $\boldsymbol{X}_{\boldsymbol{i}}$ includes age-inyear fixed effects, a binary female indicator in the HSNP census analyses which includes both girls and boys, and geographic-level fixed effects described below. ${ }^{2} u_{i j}$ represents an assumed idiosyncratic error term. We estimate similar relationships for educational outcomes for girls and boys using the HSNP census data. Because the HSNP census was carried out two years earlier, the timing of the controls in econometric models for those analyses are modified accordingly. ${ }^{3}$

For the AGI-K survey sample of girls, all analyses include age-cohort by subcounty (West, East and South) fixed effects, controlling for age-cohort effects as well as for factors common to all girls in each subcounty, including similarity in rainfall patterns within those geographic areas as reflected in figures $2 \mathrm{a}$ and $\mathrm{b}$. For the HSNP census, all analyses include location level fixed effects for the 274 locations so that identification of the causal impacts of rainfall shocks exposure is strengthened further.

To shed light on the mechanisms underlying the estimated effects on educational outcomes, we use the AGI-K survey to examine schooling expectations and healthrelated indicators, employing the same individual-level specification in equation (1). This demonstrates whether the mechanism is linked to persistence of effects on these related outcomes for the girls.

The other possible mechanism we explore is household-level economic status, considering the role of prior shocks on a set of currently available household-level resources including livestock ownership and housing conditions. Unlike for the individual child level analyses where single calendar year rainfall shocks occur at different child ages (table 1), at the household level this source of variation is unavailable (online appendix table A1). Put differently, while identification still rests on the exogenous rainfall shock at the location level, there is no variation between households in the timing of those shocks within a single location. Consequently, the only practical shock lag we can consider is whether there was a shock in 2005 in the community of residence. For household-level outcomes, therefore, we estimate

$$
y_{h j}=\beta_{0}+S_{j, 2005}+X_{h j} \beta_{1}+u_{h j},
$$

where $y_{h j}$ is the outcome for household $h$ in resident location $j . S_{j, 2005}$ is a binary indicator for whether there was a rainfall shock in household $h$ 's location $j$ in 2005, 10 years prior to the survey when shocks were widespread in Wajir (online appendix table A1

\footnotetext{
${ }^{1}$ Ages were verified several times in the AGI-K survey (but may be measured with more error in the HSNP census). GPS coordinates were taken at current residential locations. About one-third of the AGI-K sample did not continuously reside in their 2015 locations their entire lives. The survey provides former location and year of migration from which we approximate previous residential location and generate the relevant local rainfall measures.

${ }^{2}$ We do not consider econometric models controlling for other observed household-level characteristics because, even though they likely influence child education, they reflect outcomes that themselves may have been directly influenced by past rainfall shocks and are therefore endogenous.

${ }^{3}$ Although the HSNP census was administered earlier, the main rainfall shocks are the same. For those analyses, therefore, we modify the model allowing $a$ to range from 1 to $T=9$ and consider HSNP exposure from ages 6-9.
} 
and figure $2 \mathrm{~b}$ ). The set of controls in vector $\boldsymbol{X}_{\boldsymbol{h} \boldsymbol{j}}$ includes subcounty (West, East and South) fixed effects and controls for parental education and whether the parents were alive at the time of the survey. $u_{h j}$ represents an assumed household-level idiosyncratic error term.

All econometric models are estimated using ordinary least squares. Analyses with binary outcomes are interpreted as linear probability models. For models using the AGIK survey sample, standard errors are clustered at the level of the 80 AGI-K survey villages and for models using the HSNP census, standard errors are clustered at the household level.

\section{Summary statistics}

Both samples reflect the low education and high poverty levels that characterize Wajir County.

\subsection{Adolescent Girls Initiative-Kenya survey sample}

The AGI-K survey sample indicates that nearly 90 per cent of households own livestock, primarily goats, sheep and chickens, and for some, cows and highly valuable camels. Less than one-quarter own any agricultural land, including pasture. Assessment of various factors related to poverty confirm it is a poor population. More than half of the households had gone without food for at least one day in the previous month. Fifty per cent report that they did not have enough savings or something that could be readily sold to meet an expenditure need of 1,000 Kenyan Shillings (KSh) ( US\$10) and a quarter could not meet an expenditure need of KSh5000 ( US\$50). Less than 1 per cent of households have electricity or running water in the home. Formal adult education is minimal, with fewer than 2 per cent of mothers and 5 per cent of fathers ever having enrolled in school. Despite generally high residential mobility in the county, 90 per cent had lived in their current location for at least five years and consequently most child schooling has taken place while there. 92 per cent identify as Somali.

A full quarter of the girls had never enrolled in school (table 2). Of the three-quarters who had, many did so late, not starting until ages 8,9 or 10. The average grade level of girls was 2.9, already higher than their parents. Less than 15 per cent, however, had completed grade 6 or higher. On average girls were more than three grades behind for their age compared to where they would be if they had begun primary school at the recommended starting age of 6 and completed one grade each year. By that measure, less than 15 per cent were on or ahead of schedule. Despite the relatively low levels of schooling, however, among girls who had not yet completed primary school more than 85 per cent indicated that finishing primary school was important or very important to them. Of those, about two-thirds assessed the probability that they would complete primary school as high, greater than $50-50$.

One-third of the girls read all four of the literacy test sentences correctly and the average number correct was 1.6. The average score on the mathematics assessment was 16.0 out of 26 (SD 10.0). Twenty per cent earned a perfect score, with an additional 20 per cent answering at least 23 out of 26 correctly. The average number correct on the Raven test was 7.2 (SD 3.0) out of 18 and about 10 per cent answered 11 or more correctly. Selfassessment of health was also high, above 8 (SD 1.7) on a scale of 1-10. Nevertheless, nearly 50 per cent reported an illness in the past month. The most common illnesses were fever and night sweats, with smaller percentages reporting fatigue or diarrhea, coughing 
Table 2. Summary statistics for 2015 AGI-K survey sample (girls 11-14)

\begin{tabular}{|c|c|c|c|c|c|}
\hline \multirow[b]{2}{*}{ Statistics } & \multicolumn{5}{|c|}{ Age } \\
\hline & 11 & 12 & 13 & 14 & All \\
\hline Ever enrolled $(=1)$ & 0.772 & 0.752 & 0.722 & 0.767 & 0.754 \\
\hline Currently enrolled $(=1)$ & 0.735 & 0.713 & 0.687 & 0.724 & 0.715 \\
\hline Enrolled by age $8(=1)$ & 0.359 & 0.352 & 0.303 & 0.382 & 0.349 \\
\hline Enrolled by age $9(=1)$ & 0.527 & 0.479 & 0.460 & 0.508 & 0.494 \\
\hline Enrolled by age $10(=1)$ & 0.680 & 0.613 & 0.571 & 0.605 & 0.619 \\
\hline Grades completed & $\begin{array}{c}2.025 \\
(1.680)\end{array}$ & $\begin{array}{c}2.681 \\
(2.109)\end{array}$ & $\begin{array}{c}3.104 \\
(2.434)\end{array}$ & $\begin{array}{c}4.160 \\
(2.869)\end{array}$ & $\begin{array}{c}2.924 \\
(2.394)\end{array}$ \\
\hline Read Swahili correctly $(=1)$ & 0.279 & 0.407 & 0.424 & 0.563 & 0.411 \\
\hline Read English correctly $(=1)$ & 0.215 & 0.337 & 0.370 & 0.533 & 0.355 \\
\hline Read All correctly $(=1)$ & 0.208 & 0.327 & 0.362 & 0.524 & 0.524 \\
\hline Math test (\# correct out of 26) & $\begin{array}{l}14.237 \\
(9.573)\end{array}$ & $\begin{array}{l}15.995 \\
(9.961)\end{array}$ & $\begin{array}{c}16.078 \\
(10.287)\end{array}$ & $\begin{array}{c}18.274 \\
(10.058)\end{array}$ & $\begin{array}{c}16.042 \\
(10.047)\end{array}$ \\
\hline Raven (\# correct of 18 ) & $\begin{array}{c}6.881 \\
(2.695)\end{array}$ & $\begin{array}{c}7.226 \\
(2.971)\end{array}$ & $\begin{array}{c}7.103 \\
(3.139)\end{array}$ & $\begin{array}{c}7.630 \\
(3.191)\end{array}$ & $\begin{array}{c}7.195 \\
(2.999)\end{array}$ \\
\hline Finish primary important $(=1)$ & 0.884 & 0.855 & 0.859 & 0.868 & 0.866 \\
\hline High probability finish primary $(=1)$ & 0.598 & 0.630 & 0.612 & 0.601 & 0.611 \\
\hline Self-rated health last month (1-10) & $\begin{array}{c}8.182 \\
(1.711)\end{array}$ & $\begin{array}{c}8.276 \\
(1.652)\end{array}$ & $\begin{array}{c}8.315 \\
(1.572)\end{array}$ & $\begin{array}{c}8.216 \\
(1.732)\end{array}$ & $\begin{array}{c}8.247 \\
(1.667)\end{array}$ \\
\hline Illness in last month $(=1)$ & 0.442 & 0.463 & 0.499 & 0.484 & 0.470 \\
\hline Worried about their health $(=1)$ & 0.385 & 0.331 & 0.366 & 0.340 & 0.355 \\
\hline$N$ & 565 & 630 & 489 & 463 & 2,147 \\
\hline
\end{tabular}

Notes: Standard deviations shown in parentheses for non-binary variables. Math and reading tests $(N=2,135)$ and Raven $(N=2,030)$ have some missing outcomes. Every other problem from the Raven Matrices AA, AB and BB was administered, for a total of 18 problems. Finishing primary variables conditional on not having already completed primary $(N=2,043)$.

or vomiting. In a separate module of the questionnaire asking about different concerns the girls may have, more than one-third reported being worried about their health.

\subsection{Hunger and Safety Net Programme census}

In the HSNP census, more than 70 per cent of households own livestock and 40 per cent report herding or other animal-related activities as the principal occupation of the main provider. Less than 5 per cent own land for cultivation. Based on a proxy means test using various assets and demographic characteristics, HSNP categorized 50 per cent of households as very poor and a further 45 per cent as poor (Merttens, 2018). Similar to the AGI-K sample, less than 1 per cent of households have electricity or running water in the home. 95 per cent of household heads report no grades completed.

We examine individuals' ages 9-14 years old from the HSNP census. Because it includes Wajir North, the sample has broader coverage than the AGI-K sample and a smaller percentage of children had ever enrolled in school: about 50 per cent of girls and 60 per cent of boys (see online appendix table A2). Current enrollments are even lower, 30 per cent for girls and 40 per cent for boys. Enrollment rates may be substantially higher 
in the AGI-K sample because by design all survey clusters in that sample had a school within $3 \mathrm{~km}$. Completed grades show that education has been increasing compared to the levels described above for adults, but also show that there remain substantial gender differences, on average half a grade and even larger for the older adolescents. Similar to the girls in the AGI-K sample, girls and boys were on average more than two grades behind for their age.

\section{Results}

\subsection{Educational outcomes}

Local rainfall shocks in the first years of life negatively and significantly affected all educational outcomes examined in the AGI-K survey sample (table 3). For example, a rainfall shock at age 0 , i.e., during the first year of life, reduced the probability of ever having enrolled in school by 16.9 percentage points and of having enrolled by age 8 by 20.7 percentage points. It also reduced years of schooling completed by 0.8 grades. The same shock lowered achievement and cognitive skills, reducing the probability of correctly answering all four reading questions by 13.0 percentage points and the math and Raven test scores by 0.2 SD or more. A rainfall shock at the age of 1 also significantly affected several of the outcomes, though to a lesser extent. Shocks at later ages, although nearly all with negative point estimates, are mostly insignificant until age 5 at which point ever enrolled in school, completed grades and the literacy test score were all significantly reduced. Shocks at age 5, however, had no significant effect on the Raven, consistent with an interpretation of the test as one related more to ability and cognitive development in early life than to what is learned in school, and for which early life shocks are the only ones that are significant. After age 5 none of the shocks is significant, except at age 6 for completed grades; this may be because the weather patterns in the region were such that there were fewer 1 SD rainfall shocks at the older ages (table 1) for the sample we examine. ${ }^{4}$

Results from the 2015 AGI-K survey sample demonstrate that rainfall shocks influence female educational development and nonverbal cognitive skills. We replicate the analyses for the measures ever enrolled in school and completed grades using the much larger HSNP census. Because there are fewer available educational measures in the census, we also examine current enrollment, recognizing that it is a less cumulative measure than the others. The first two columns of table 4 present the results estimating equation (1) and controlling for the 274 locational fixed effects for enrollment for both girls and boys. They corroborate the importance of early life (at ages 1 and 2) as well as later ages for ever enrolled in the survey sample. Indeed, they demonstrate that at nearly all of the ages, shocks reduce the enrollment probabilities by around 5-9 percentage points. Columns (3) and (4) present results for completed grades for girls and boys separately. Although as seen for enrollments the specific ages at which shocks are significant differ slightly compared to the AGI-K survey results, possibly related to differences in timing of measurement in the calendar year or measurement error in reported ages in the census, results for girls are broadly similar to those in table 3 and do not appear to be substantially attenuated as hypothesized in section 4.2. The results are also similar for boys though generally smaller than for girls, even if not significantly different. In the final

\footnotetext{
${ }^{4}$ If we consider instead of 1.0 a lower cut-off to define a rainfall shock, such as $0.66 \mathrm{SD}$, the percentage of locations with shocks increases, and there is modestly more evidence of significant negative effects at the older school ages.
} 
Table 3. Rainfall shocks and educational outcomes (AGI-K survey sample, girls 11-14)

\begin{tabular}{|c|c|c|c|c|c|c|}
\hline & $\begin{array}{l}\text { Ever enrolled } \\
\qquad(=1)\end{array}$ & $\begin{array}{l}\text { Enrolled by age } \\
\text { eight }(=1)\end{array}$ & $\begin{array}{l}\text { Completed } \\
\text { grades }\end{array}$ & $\begin{array}{l}\text { Reading test-all } \\
\text { correct }(=1)\end{array}$ & $\begin{array}{l}\text { Math test } \\
z \text {-score }\end{array}$ & $\begin{array}{c}\text { Raven test } \\
z \text {-score }\end{array}$ \\
\hline & (1) & (2) & (3) & (4) & (5) & (6) \\
\hline Rainfall shock at age 0 & $\begin{array}{l}-0.169^{\star \star} \\
(0.081)\end{array}$ & $\begin{array}{l}-0.207^{\star * \star} \\
(0.068)\end{array}$ & $\begin{array}{c}-0.840^{\star \star \star} \\
(0.312)\end{array}$ & $\begin{array}{l}-0.130^{\star \star} \\
(0.052)\end{array}$ & $\begin{array}{c}-0.476^{\star \star \star} \\
(0.163)\end{array}$ & $\begin{array}{r}-0.215^{\star} \\
(0.114)\end{array}$ \\
\hline Rainfall shock at age 1 & $\begin{array}{r}-0.089 \\
(0.066)\end{array}$ & $\begin{array}{c}-0.106^{\star} \\
(0.055)\end{array}$ & $\begin{array}{l}-0.617^{\star \star \star} \\
(0.225)\end{array}$ & $\begin{array}{r}-0.061 \\
(0.047)\end{array}$ & $\begin{array}{l}-0.323^{* *} \\
(0.128)\end{array}$ & $\begin{array}{c}-0.199 \\
(0.124)\end{array}$ \\
\hline Rainfall shock at age 2 & $\begin{array}{r}-0.026 \\
(0.056)\end{array}$ & $\begin{array}{r}-0.058 \\
(0.049)\end{array}$ & $\begin{array}{r}-0.201 \\
(0.285)\end{array}$ & $\begin{array}{c}0.014 \\
(0.053)\end{array}$ & $\begin{array}{r}-0.035 \\
(0.131)\end{array}$ & $\begin{array}{c}-0.068 \\
(0.106)\end{array}$ \\
\hline Rainfall shock at age 3 & $\begin{array}{c}-0.023 \\
(0.061)\end{array}$ & $\begin{array}{r}-0.061 \\
(0.052)\end{array}$ & $\begin{array}{c}-0.274 \\
(0.330)\end{array}$ & $\begin{array}{r}-0.009 \\
(0.053)\end{array}$ & $\begin{array}{c}-0.153 \\
(0.126)\end{array}$ & $\begin{array}{r}-0.168 \\
(0.147)\end{array}$ \\
\hline Rainfall shock at age 4 & $\begin{array}{c}-0.065 \\
(0.055)\end{array}$ & $\begin{array}{c}-0.085 \\
(0.055)\end{array}$ & $\begin{array}{c}-0.442 \\
(0.370)\end{array}$ & $\begin{array}{c}-0.022 \\
(0.053)\end{array}$ & $\begin{array}{c}-0.205 \\
(0.125)\end{array}$ & $\begin{array}{c}-0.085 \\
(0.163)\end{array}$ \\
\hline Rainfall shock at age 5 & $\begin{array}{c}-0.141^{\star} \\
(0.075)\end{array}$ & $\begin{array}{r}-0.126 \\
(0.086)\end{array}$ & $\begin{array}{l}-0.825^{\star \star \star} \\
(0.305)\end{array}$ & $\begin{array}{l}-0.217^{\star \star \star} \\
(0.060)\end{array}$ & $\begin{array}{c}-0.243 \\
(0.164)\end{array}$ & $\begin{array}{c}0.290 \\
(0.273)\end{array}$ \\
\hline Rainfall shock at age 6 & $\begin{array}{c}0.070 \\
(0.070)\end{array}$ & $\begin{array}{c}-0.164 \\
(0.117)\end{array}$ & $\begin{array}{r}-0.665^{\star} \\
(0.365)\end{array}$ & $\begin{array}{c}0.067 \\
(0.101)\end{array}$ & $\begin{array}{c}0.090 \\
(0.272)\end{array}$ & $\begin{array}{r}-0.195 \\
(0.294)\end{array}$ \\
\hline Rainfall shock at age 7 & $\begin{array}{c}-0.146 \\
(0.170)\end{array}$ & $\begin{array}{r}-0.046 \\
(0.110)\end{array}$ & $\begin{array}{r}-0.156 \\
(0.869)\end{array}$ & $\begin{array}{c}0.033 \\
(0.113)\end{array}$ & $\begin{array}{c}-0.177 \\
(0.393)\end{array}$ & $\begin{array}{c}-0.215 \\
(0.176)\end{array}$ \\
\hline $\mathrm{N}$ & 2,147 & 2,147 & 2,147 & 2,135 & 2,135 & 2,030 \\
\hline$p$-value overall $\mathrm{F}$ test & 0.012 & $<0.001$ & $<0.001$ & $<0.001$ & $<0.001$ & $<0.001$ \\
\hline
\end{tabular}

Notes: Ever enrolled, enrolled by age eight and reading test (all four correct) are binary variables. *** indicates significance at $p<0.01$, ** at $p<0.05$ and * at $p<0.10$. All models include (but do not show) single age subcounty dummies for the four ages and three subcounties. All models estimated using ordinary least squares. Standard errors are calculated allowing for clustering at the (80) survey cluster level. Sample sizes smaller than 2,147 due to missing outcome measures. 
Table 4. Rainfall shocks and educational outcomes (HSNP census, girls and boys 9-14)

\begin{tabular}{|c|c|c|c|c|c|}
\hline & \multirow{2}{*}{$\begin{array}{l}\text { Ever enrolled } \\
\qquad(=1)\end{array}$} & \multirow{2}{*}{$\begin{array}{c}\begin{array}{c}\text { Currently } \\
\text { enrolled }(=1)\end{array} \\
\text { All } \\
(2)\end{array}$} & \multicolumn{3}{|c|}{ Completed grades } \\
\hline & & & $\begin{array}{c}\text { Female } \\
\text { (3) }\end{array}$ & $\begin{array}{l}\text { Male } \\
(4)\end{array}$ & $\begin{array}{l}\text { All } \\
(5)\end{array}$ \\
\hline Rainfall shock age 1 & $\begin{array}{c}-0.081^{\star *} \\
(0.034)\end{array}$ & $\begin{array}{c}-0.081^{\star \star} \\
(0.034)\end{array}$ & $\begin{array}{c}-0.805^{\star \star \star} \\
(0.275)\end{array}$ & $\begin{array}{c}-0.635^{\star \star} \\
(0.254)\end{array}$ & $\begin{array}{c}-0.716^{\star \star \star} \\
(0.179)\end{array}$ \\
\hline Rainfall shock age 2 & $\begin{array}{c}-0.067^{\star \star} \\
(0.034)\end{array}$ & $\begin{array}{c}-0.072^{\star \star} \\
(0.033)\end{array}$ & $\begin{array}{c}-0.664^{\star \star} \\
(0.275)\end{array}$ & $\begin{array}{c}-0.482^{\star} \\
(0.251)\end{array}$ & $\begin{array}{c}-0.566^{\star \star \star} \\
(0.179)\end{array}$ \\
\hline Rainfall shock age 3 & $\begin{array}{c}-0.062^{\star} \\
(0.035)\end{array}$ & $\begin{array}{c}-0.091^{\star \star \star} \\
(0.034)\end{array}$ & $\begin{array}{l}-0.401 \\
(0.283)\end{array}$ & $\begin{array}{l}-0.380 \\
(0.260)\end{array}$ & $\begin{array}{c}-0.398^{\star \star} \\
(0.185)\end{array}$ \\
\hline Rainfall shock age 4 & $\begin{array}{c}-0.059^{\star} \\
(0.034)\end{array}$ & $\begin{array}{c}-0.083^{\star *} \\
(0.033)\end{array}$ & $\begin{array}{l}-0.215 \\
(0.278)\end{array}$ & $\begin{array}{l}-0.162 \\
(0.253)\end{array}$ & $\begin{array}{l}-0.189 \\
(0.180)\end{array}$ \\
\hline Rainfall shock age 5 & $\begin{array}{c}-0.056^{\star} \\
(0.033)\end{array}$ & $\begin{array}{c}-0.091^{\star \star \star} \\
(0.033)\end{array}$ & $\begin{array}{c}0.023 \\
(0.259)\end{array}$ & $\begin{array}{c}0.185 \\
(0.239)\end{array}$ & $\begin{array}{c}0.105 \\
(0.169)\end{array}$ \\
\hline Rainfall shock age 6 & $\begin{array}{c}-0.057^{\star} \\
(0.030)\end{array}$ & $\begin{array}{c}-0.089^{\star \star \star} \\
(0.030)\end{array}$ & $\begin{array}{l}-0.235 \\
(0.244)\end{array}$ & $\begin{array}{c}0.231 \\
(0.224)\end{array}$ & $\begin{array}{c}0.012 \\
(0.161)\end{array}$ \\
\hline Rainfall shock age 7 & $\begin{array}{l}-0.006 \\
(0.032)\end{array}$ & $\begin{array}{l}-0.019 \\
(0.032)\end{array}$ & $\begin{array}{c}0.213 \\
(0.272)\end{array}$ & $\begin{array}{l}-0.066 \\
(0.229)\end{array}$ & $\begin{array}{c}0.026 \\
(0.172)\end{array}$ \\
\hline Rainfall shock age 8 & $\begin{array}{c}-0.059^{\star \star} \\
(0.026)\end{array}$ & $\begin{array}{c}-0.082^{\star \star \star} \\
(0.026)\end{array}$ & $\begin{array}{c}-0.626^{\star \star \star} \\
(0.228)\end{array}$ & $\begin{array}{l}-0.067 \\
(0.222)\end{array}$ & $\begin{array}{c}-0.302^{\star \star} \\
(0.153)\end{array}$ \\
\hline Rainfall shock age 9 & $\begin{array}{l}-0.029 \\
(0.028)\end{array}$ & $\begin{array}{l}-0.044 \\
(0.028)\end{array}$ & $\begin{array}{l}-0.426 \\
(0.263)\end{array}$ & $\begin{array}{l}-0.143 \\
(0.226)\end{array}$ & $\begin{array}{c}-0.283^{\star} \\
(0.169)\end{array}$ \\
\hline Female & $\begin{array}{c}-0.104^{\star \star \star} \\
(0.003)\end{array}$ & $\begin{array}{c}-0.080^{\star \star \star} \\
(0.003)\end{array}$ & & & $\begin{array}{c}-0.581^{\star \star \star} \\
(0.018)\end{array}$ \\
\hline$N$ & 93,418 & 93,418 & 42,157 & 51,261 & 93,418 \\
\hline$p$-value overall $\mathrm{F}$ test & $<0.001$ & $<0.001$ & $<0.001$ & $<0.001$ & $<0.001$ \\
\hline
\end{tabular}

Notes: ${ }^{* *}$ indicates significance at $p<0.01$, ${ }^{* *}$ at $p<0.05$ and * at $p<0.10$. All models include (but do not show) age dummy variables and location fixed effects. Standard errors are calculated allowing for clustering at the household level.

column we combine girls and boys; the full sample demonstrates that rainfall shocks in early life substantially reduced completed grades and that shocks in later childhood around the years of typical school entry also are important.

\subsection{Individual-and household-level mechanisms}

We consider schooling attitudes and expectations for girls who had not yet completed primary school estimating equation (1) (table 5). Shocks at age 1, as well as at ages 3 and 4 , are associated with lower importance to the girl of finishing primary school as well as with lower expectations that she would finish. Shocks at age 7 also reduce her expectation of finishing primary school. There are negative coefficients on shocks at most other ages, but these were not statistically significant. Because these attitudes and expectations are almost certainly related to actual current schooling status, we also examined whether the rainfall shocks remained significant conditional on actual schooling levels. If the observed associations operate only through achieved levels of schooling (so that the attitudes and expectations mainly reflect already-achieved schooling levels), we anticipate that the role of shocks would diminish once we control for schooling. We included two 
summary measures of schooling progress as additional controls in equation (1), whether the girl had enrolled in school by age 8 and her currently completed grades. Findings for the influence of the shock measures shown are virtually unchanged with the addition of these controls (not shown). This suggests that there is an additional effect of rainfall shocks on attitudes and expectations beyond the impacts of rainfall shocks on schooling itself.

With these data we can only speculate as to what might drive these effects, but one possibility is that persistent effects on cognitive skills (as found for the Raven) diminish the expectation of successfully completing primary school. Relatedly, there may be persistent effects of early life shocks on health, hindering school success. We provide evidence on the health mechanism using the self-reported health indicators in the final three columns of table 5 and find some evidence that rainfall shocks in the first year of life (at age 0 ) are linked to a lower health assessment, higher illness in the last month and greater concern about personal health.

The other principal mechanism we examine is the persistence of effects of historical rainfall shocks on household resources, estimating equation (2) for the set of indicators shown in table 6. Although there is no significant effect on whether the household has at least one child in school, a rainfall shock in 2005 in the location of residence led to one-third less spending on schooling in 2015. On the extensive margin, the shock a decade earlier reduced the probability that a household owned land but not that it owned animals. The shock did, however, reduce total livestock units (FAO, 2003) by about 10 per cent. Part of this reduction appears to operate via substitution away from camels toward milk cows or cattle, with fewer significant changes in ownership of other types of animals (not shown). There is also some evidence of poorer housing conditions and those experiencing a shock were less likely to have a metal roof or access to any type of latrine. Assessment of the effect of rainfall shocks on indicators of household liquidity are mixed, suggesting higher liquidity for smaller expenditure amounts of KSh1,000 ( US\$10) but lower liquidity for modestly larger amounts of KSh5,000 ( US\$50). These results are not unlike findings from Ethiopia which demonstrate that weather uncertainty can influence livestock portfolio holdings that in turn influence liquidity (Abay and Jensen, 2020) but with lower overall wealth. Overall, assessment of the influence of rainfall shocks on resources and characteristics of households suggests a number of persistent negative effects after 10 years.

\subsection{Discussion and further robustness considerations}

The results confirm the importance of rainfall shocks at different ages on adolescent educational outcomes in a semi-arid setting dominated by pastoral-based livelihoods. Moreover, they demonstrate substantive effects. Calendar year shock patterns made clear that there were only two specific years in which individuals in Wajir experienced rainfall shocks as we measure them of one or more SD below the local historical average. Although the strict interpretation of the results is that if a girl experienced shocks in multiple years, the effects would be additive and therefore larger, in the AGI-K survey sample, 43 per cent of girls did not experience a shock at any age from 0 to 7 , and 55 per cent experienced exactly one shock. Consequently, although the results suggest that multiple rainfall shocks during childhood could be even more detrimental to educational outcomes, few girls were exposed to more than one such shock. Exposure patterns were similar in the HSNP census, with 40 per cent experiencing no shocks and 58 per cent one shock. 
Table 5. Rainfall shocks, schooling expectations and health indicators (AGI-K survey sample, girls 11-14)

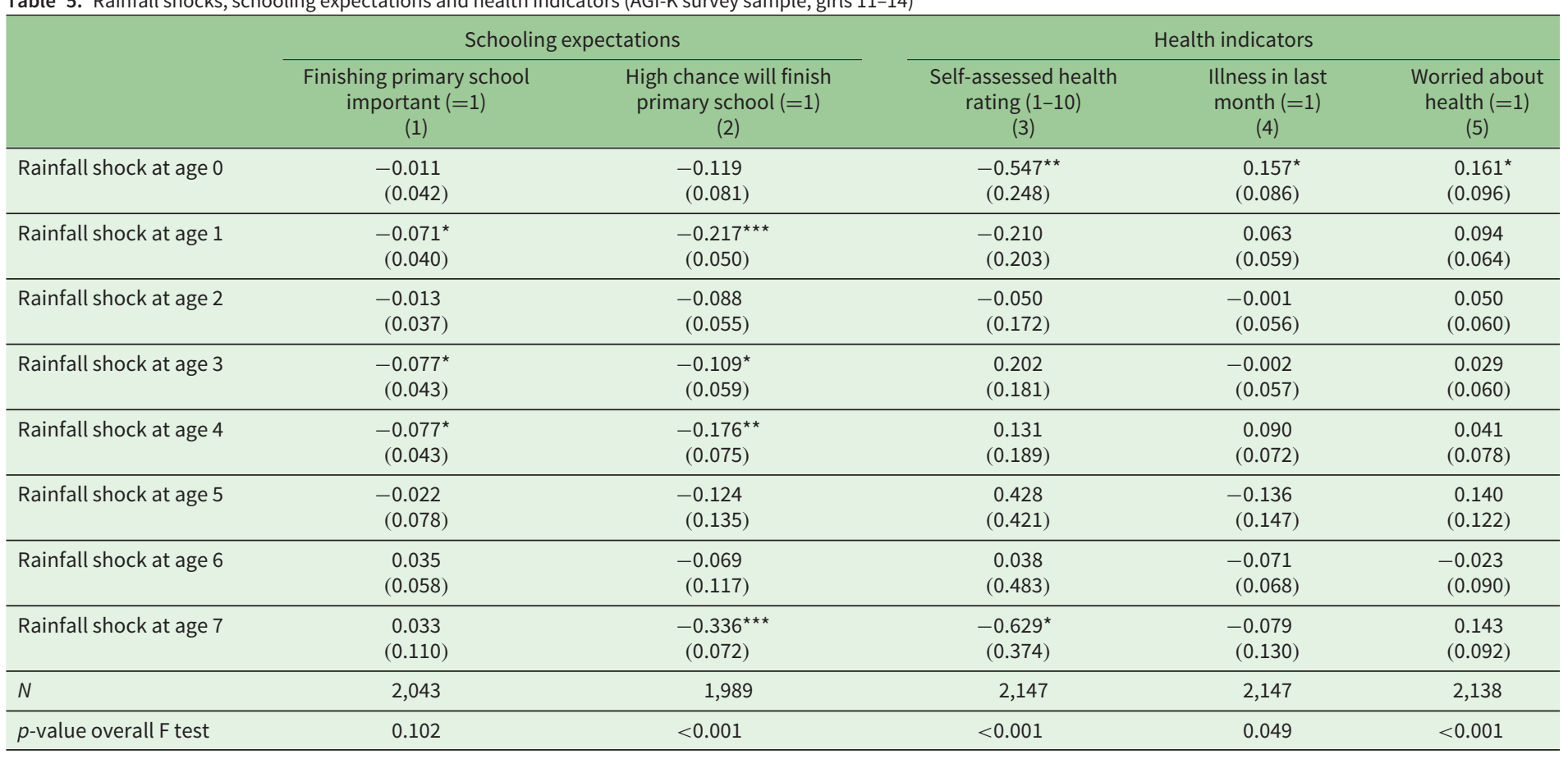

Notes: Outcomes in columns (1), (2), (4) and (5) are binary variables. ${ }^{\star * \star}$ indicates significance at $p<0.01,{ }^{* \star}$ at $p<0.05$ and * at $p<0.10$. All models include (but do not show) single age subcounty dummies for the four ages and three subcounties. All models estimated using ordinary least squares. Standard errors are calculated allowing for clustering at the (80) survey cluster level. Sample sizes smaller than 2,147 due to questions conditional on not having completed primary school in columns (1) and (2) and missing outcome measures in column (5). 
Table 6. Rainfall shocks and household-level resources and characteristics (AGI-K survey sample)

\begin{tabular}{|c|c|c|}
\hline & $\begin{array}{l}\text { Mean } \\
(1)\end{array}$ & $\begin{array}{l}\text { Effect of } 2005 \text { rainfall shock } \\
\text { (2) }\end{array}$ \\
\hline \multicolumn{3}{|l|}{ Education-related } \\
\hline At least one child in school $(=1)$ & $\begin{array}{c}0.919 \\
(0.273)\end{array}$ & $\begin{array}{c}-0.021 \\
(0.016)\end{array}$ \\
\hline Total expenditures on schooling last year (Ksh) & $\begin{array}{c}18,752 \\
-24,347\end{array}$ & $\begin{array}{c}-6,627^{\star * *} \\
(1,295)\end{array}$ \\
\hline \multicolumn{3}{|l|}{ Livestock-related } \\
\hline Owns agricultural/pasture land $(=1)$ & $\begin{array}{c}0.233 \\
(0.423)\end{array}$ & $\begin{array}{l}-0.202^{\star * \star} \\
(0.023)\end{array}$ \\
\hline Owns animals $(=1)$ & $\begin{array}{c}0.880 \\
(0.325)\end{array}$ & $\begin{array}{c}-0.009 \\
(0.018)\end{array}$ \\
\hline Livestock units $^{\mathrm{a}}$ & $\begin{array}{l}8.873 \\
(9.444)\end{array}$ & $\begin{array}{r}-0.929^{*} \\
(0.486)\end{array}$ \\
\hline Owns camel $(=1)$ & $\begin{array}{c}0.398 \\
(0.490)\end{array}$ & $\begin{array}{l}-0.114^{\star \star \star} \\
(0.028)\end{array}$ \\
\hline Owns milk cow/bull (=1) & $\begin{array}{l}0.230 \\
(0.421)\end{array}$ & $\begin{array}{l}0.078^{* \star *} \\
(0.022)\end{array}$ \\
\hline \multicolumn{3}{|l|}{ Housing characteristics and assets } \\
\hline More than one room for sleeping $(=1)$ & $\begin{array}{c}0.111 \\
(0.315)\end{array}$ & $\begin{array}{c}0.013 \\
(0.017)\end{array}$ \\
\hline Metal roof $(=1)$ & $\begin{array}{c}0.105 \\
(0.307)\end{array}$ & $\begin{array}{l}-0.030^{\star *} \\
(0.013)\end{array}$ \\
\hline Access to latrine $(=1)$ & $\begin{array}{c}0.161 \\
(0.367)\end{array}$ & $\begin{array}{l}-0.048^{\star \star} \\
(0.019)\end{array}$ \\
\hline Owns tv $(=1)$ & $\begin{array}{c}0.017 \\
(0.130)\end{array}$ & $\begin{array}{l}0.010 \\
(0.008)\end{array}$ \\
\hline \multicolumn{3}{|l|}{ Liquidity } \\
\hline $\begin{array}{l}\text { Household went without food at least } 1 \\
\text { Day last month }(=1)\end{array}$ & $\begin{array}{c}0.508 \\
(0.500) \\
\end{array}$ & $\begin{array}{r}-0.034 \\
(0.029) \\
\end{array}$ \\
\hline \multicolumn{3}{|l|}{ Household has enough savings/something to sell } \\
\hline If need 1,000 Kenyan Shillings $(=1)$ & $\begin{array}{c}0.499 \\
(0.500)\end{array}$ & $\begin{array}{l}0.145^{\star * *} \\
(0.029)\end{array}$ \\
\hline If need 5,000 Kenyan Shillings ( $=1$ ) & $\begin{array}{c}0.263 \\
(0.440)\end{array}$ & $\begin{array}{l}0.004 \\
(0.024)\end{array}$ \\
\hline If need 10,000 Kenyan Shillings $(=1)$ & 0.136 & $-0.049^{\star \star \star}$ \\
\hline
\end{tabular}

Notes: $N=2,030$ unless otherwise noted. Means and standard deviations (in parentheses) in column (1). Estimated coefficients and standard errors (in parentheses) in column (2) treating each variable as the dependent variable in a regression on the 2005 rainfall shock indicator, subcounty dummies and controls for parental education and whether alive. ${ }^{* \star *}$ indicates significance at $p<0.01,{ }^{* *}$ at $p<0.05$ and ${ }^{*}$ at $p<0.10$.

a Livestock units calculated as $1.1 \times$ camels $+0.8 \times$ horses/donkeys/mules $+0.5 \times$ cattle $+0.1 \times$ sheep/goats $+0.01 \times$ chickens (FAO, 2013). 
Examining the underlying mechanisms, we find some suggestive evidence that shocks lead to persistent effects on the children themselves, and stronger evidence that there are persistent effects on their households. Consistent with the broader literature, rainfall shocks in early life affected cognitive development and the self-reported health of girls. Furthermore, the rainfall shock in 2005 had persistent effects on household resources and resulted in lower expenditure on schooling ten years later. Consequently, both types of potential mechanisms appear to be contributing to lower human capital in adolescence. These findings are important for policy development because they suggest even effective short-lived interventions may not be able to fully mitigate the influence of household shocks whose effects can endure for years. Program interventions or policies may need to be in place more consistently over time.

Similar to many low resource settings, the policy landscape in Wajir is complex, for example including the large HSNP unconditional cash transfer program begun in 2009. Such targeted programs can counteract or confound the effects of rainfall shocks. We carried out further analysis incorporating controls for HSNP availability; the main results related to the effects of rainfall shocks were unchanged. A small literature examining the interrelationships between cash transfer programs and past or current rainfall shocks suggests those links can be complicated (Asfaw et al., 2017; Adhvaryu et al., 2018; Dietrich and Schmerzeck, 2019). Since we know of no similarly large intervention programs operating in Wajir at the time of the last major shock in 2005, we explored the possible interactions between early-life shocks with later-in-life HSNP availability. Because of its non-random program roll-out, we cannot causally identify the overall average program effect of the HSNP itself. But an intent-to-treat difference-in-difference approach focusing on children who suffered early life shocks and for whom HSNP was available in their locality when they were at school-entry ages suggests a potential role of the unconditional cash transfer program in mitigating the effects of early-life shocks later in life (see online appendix). This underscores the possibility that social programs can help lead to catch-up, which may have mitigated the impact of exogenous shocks for some girls and therefore attenuated our estimates.

\subsection{Strengths and limitations}

Strengths of the analysis include combining long-term historical rainfall data at lowgeographic level in a semi-arid context with two separate data sources on individuals, one of which provides schooling, achievement and cognitive outcomes, as well as indicators of the potential underlying mechanisms. The rainfall data provide plausibly exogenous variation, increasing confidence in the causal interpretation for the estimates. Causal interpretation in the reduced form estimates is further strengthened by additional controls including age and geographic-level fixed effects.

Nevertheless, there are some limitations. First, although deviations from historical average rainfall are often used as a proxy for drought, no single indicator can provide a comprehensive picture since drought is multidimensional. Other factors including those related to rainfall, vegetation, soil moisture, access to agricultural resources and alternative irrigation, and variation in regional food prices all may contribute to drought severity and duration (Vicente-Serrano, 2016; Dietrich and Schmerzeck, 2019). A second limitation is that HSNP operated in the region, as well as other social protection programs, including the World Food Programme (WFP) which has operated in Wajir County since 2006. Consequently, it is possible that the effects of shocks interact with the existing social programs in ways we were not able to rigorously identify or control for, as 
such programs (cash or in-kind) could relax resource constraints at the household level. In the online appendix, however, we provide evidence that the extent of resulting bias from the most important of these programs (HSNP) is likely minimal. A third limitation is that there are probable misclassification or measurement errors for age and past residential location in the AGI-K survey sample, and to an even greater extent in the HSNP census sample where we must make the relatively strong assumption that adolescents have not relocated. As discussed in section 4.2, these problems possibly lead to attenuation bias, although the similarity in results across the two samples suggests such bias may be modest.

\section{Conclusions}

Using two samples from pastoralist Wajir County, Kenya, combined with historical rainfall data, we examined the effect of local rainfall shocks indicative of meteorological drought at different stages of childhood on educational outcomes in early adolescence. Rainfall shocks in the first few years of life and at ages when children should be starting primary school negatively, and substantially, affected enrollment and completed grades in a setting where they were already low. Using comprehensive survey data available for a sample of girls, we also found that early life shocks reduced both achievement and cognitive test scores. Exploration of the underlying mechanisms points to the importance of early life rainfall shocks having persistent effects on the individuals via their cognitive development as well as their health. Furthermore, rainfall shocks had persistent effects on household resources available for investment in child schooling.

Although the effects of shocks on educational outcomes likely differ in other contexts, for example varying with different household-level capacities for anticipatory or compensatory behaviors, their patterns and persistence in semi-arid Wajir are important for policy development more widely. Short-lived programs that do not cover both early life and later school entry ages of all children may not be able to fully mitigate the enduring influence of rainfall shocks. Programs and policies need to be in place more consistently over time to adequately protect investment in human capital. Such protection is particularly important for young adolescent girls transitioning into adulthood and for whom lower schooling is linked to early marriage and higher fertility.

Supplementary material. The supplementary material for this article can be found at https://doi.org/10. 1017/S1355770X20000406.

Acknowledgements. The authors thank Marcos Barrozo Filho and Mohamed Hussein for research assistance in data preparation; participants at the IUSSP 2017 conference including Gilvan Guedes and Kathryn Grace; and two anonymous referees for valuable comments. HSNP provided the census data. All remaining errors are our own. This research has been funded by UK aid from the UK government. The views expressed do not necessarily reflect official policies of the UK government.

\section{References}

Abay KA and Jensen ND (2020) Access to markets, weather risk, and livestock production decisions: evidence from Ethiopia. Agricultural Economics 51, 577-593.

Adhvaryu A, Molina T, Nyshadham A and Tamayo J (2018) Helping children catch up: early life shocks and the PROGRESA experiment. NBER Working Paper 24848. National Bureau of Economic Research, Cambridge, MA.

Agricultural Sector Development Support Programme (ASDSP) (2014) Household Survey Baseline Report: Wajir County. Ministry of Agriculture, Livestock, and Fisheries, Nairobi, Kenya. 
Akresh R, Bagby E, de Walque D and Kazianga H (2012) Child labor, schooling, and child ability. World Bank Policy Research Working Paper No. 5965. https://doi.org/10.1596/1813-9450-5965.

Alderman H, Hoddinott J and Kinsey B (2006) Long term consequences of early childhood malnutrition. Oxford Economic Papers 58, 450-474.

Asfaw S, Carraro A, Davis B, Handa S and Seidenfeld D (2017) Cash transfer programmes, weather shocks and household welfare: evidence from a randomised experiment in Zambia. Journal of Development Effectiveness 9, 419-442.

Austrian K, Muthengi E, Mumah J, Soler-Hampejsek E, Kabiru CW, Abuya B and Maluccio JA (2016) The Adolescent Girls Initiative-Kenya (AGI-K): study protocol. BMC Public Health 16, article 210, 1-14. https://doi.org/10.1186/s12889-016-2888-1.

Beegle K, Dehejia RH and Gatti R (2006) Child labor and agricultural shocks. Journal of Development Economics 81, 80-96.

Berazneva J and Byker T (2017) Does forest loss increase human disease? Evidence from Nigeria. American Economic Review: Papers \& Proceedings 107, 516-521.

Björkman-Nyqvist M (2013) Income shocks and gender gaps in education: evidence from Uganda. Journal of Development Economics 105, 237-253.

Burke M, Gong E and Jones K (2015) Income shocks and HIV in Africa. Economic Journal 125, 1157-1189.

Corno L, Hildebrandt N and Voena A (2017) Age of marriage, weather shocks, and direction of marriage payments. NBER Working Paper 23604. National Bureau of Economic Research, Cambridge, MA.

Currie J and Vogl T (2012) Early-life health and adult circumstance in developng countries. NBER Working paper 18371. National Bureau of Economic Research, Cambridge, MA.

Davis B, Winters P, Carletto G, Covarrubias K, Quiñones EJ, Zezza A, Stamoulis K, Azzarri C and DiGiuseppe S (2010) A cross-country comparison of rural income generating activities. World Development 38, 48-63.

Dercon S, Hoddinott J and Woldehanna T (2005) Shocks and consumption in 15 Ethiopian villages 1999-2004. Journal of African Economies 14, 559-585.

Dietrich S and Schmerzeck G (2019) Cash transfers and nutrition: the role of market isolation after weather shocks. Food Policy 87, 1017-1039.

Dinkelman T (2017) Long-run health repercussions of drought shocks: evidence from South African homelands. Economic Journal 127, 1906-1939.

Fafchamps M, Udry C and Czukas K (1998) Drought and saving in West Africa: are livestock a buffer stock? Journal of Development Economics 55, 273-305.

Food and Agriculture Organization (FAO) (2003) Compendium of Agricultural-Environmental Indicators 1989-91 to 2000. Rome, Italy: Food and Agriculture Organization.

Frankenberg E and Thomas D (2018) Human capital and shocks: evidence on education, health and nutrition. In Barrett C, Carter M and Chavas JP (eds), The Economics of Poverty Traps. Chicago: University of Chicago Press, pp. 23-56.

Funk C, Peterson P, Landsfeld M, Pedreros D, Verdin J, Shukla S, Husak G, Rowland J, Harrison L, Hoell A and Michaelson J (2015) The climate hazards infrared precipitation with stations - a new environmental record for monitoring extremes. Nature-Scientific Data 2, article 150066. https://doi.org/10. 1038/sdata.2015.66.

Glewwe P and King E (2001) The impact of early childhood nutritional status on cognitive development: does the timing of malnutrition matter? World Bank Economic Review 15, 81-113.

Grace K, Davenport F, Funk C and Lerner AM (2012) Child malnutrition and climate in Sub-saharan Africa: an analysis of recent trends in Kenya. Applied Geograph, 35, 405-413.

Hoddinott J and Kinsey B (2001) Child growth in the time of drought. Oxford Bulletin of Economics and Statistics 63, 409-436.

Intergovernmental Panel on Climate Change (IPCC) (2014) Climate Change 2014 - Impacts, Adaptation and Vulnerability - Regional Aspects. Cambridge, UK: Cambridge University Press.

Kazianga $\mathbf{H}$ and Udry C (2006) Consumption smoothing? Livestock, insurance and drought in Burkina Faso. Journal of Development Economics 79, 413-446.

Kenya National Bureau of Statistics (KNBS) (2015) Kenya Demographic and Health Survey 2014. Available at http://dhsprogram.com/pubs/pdf/FR308/FR308.pdf.

Kimiti KS, Western D, Mbau JS and Wasonga OV (2018) Impacts of long-term land-use changes on herd size and mobility among pastoral households in Amboseli ecosystem Kenya. Ecological Processes 7, 1-9. 
Leight JP, Glewwe P and Park A (2015) The impact of early childhood rainfall shocks on the evolution of cognitive and non-cognitive skills. Mimeo, Williams College, Williamstown, MA.

Maccini S and Yang D (2009) Under the weather: health, schooling, and economic consequences of earlylife rainfall. American Economic Review 99, 1006-1026.

Maystadt JF and Ecker O (2014) Extreme weather and civil war: does drought fuel conflict in Somalia through livestock price shocks? American Journal of Agricultural Economics 96, 1157-1182.

Merttens F (2018) Evaluation of the Kenya Hunger Safety Net Programme Phase 2: Impact Evaluation Final Report. Oxford, UK: Oxford Policy Management.

Miguel E, Satyanath S and Sergenti E (2004) Economic shocks and civil conflict: an instrumental variables approach. Journal of Political Economy 112, 725-753.

Ministry of Agriculture, Livestock and Fisheries of Kenya (MoALF) (2017) Climate risk profile for Wajir County. Kenya County Climate Risk Profile Series. The Ministry of Agriculture, Livestock and Fisheries (MoALF), Nairobi, Kenya.

Opiyo F, Wasonga O, Nygangito M, Schilling J and Munang R (2015) Drought adaptation and coping strategies among the turkana pastoralists of northern Kenya. International Journal of Disaster Risk Science 6, 295-309.

Paxson C (1992) Using weather variability to estimate the response of savings to transitory income in Thailand. American Economic Review 82, 15-33.

Rabassa M, Skoufias E and Jacoby H (2014) Weather and child health in rural Nigeria. Journal of African Economies 23, 464-492.

Raven J, Court JH and Raven J (1984) Manual for Raven's Progressive Matrices and Vocabulary Scales. London, UK: H.K. Lewis.

Shah M and Steinberg BM (2017) Drought of opportunities: contemporaneous and long-term impacts of rainfall shocks on human capital. Journal of Political Economy 125, 527-561.

Thai Q and Falaris EM (2014) Child schooling, child health, and rainfall shocks: evidence from rural Vietnam. Journal of Development Studies 50, 1025-1037.

UWEZO (2014) Kenya National Learning Assessment. Nairobi, Kenya: Test Booklet.

Vicente-Serrano SM (2016) Drought complexity and assessment under climate change conditions. Cuadernos de Investigación Geográfica 42, 7-11.

Vimefall E, Andrén D and Levin J (2017) Ethnolinguistic background and enrollment in primary education: evidence from Kenya. African Development Review 29, 81-91.

Wydick B, Glewwe P and Rutledge L (2013) Does international child sponsorship work? A six-country study of impacts on adult life outcomes. Journal of Political Economy 121, 393-436.

Cite this article: Nübler L, Austrian K, Maluccio JA, Pinchoff J (2021). Rainfall shocks, cognitive development and educational attainment among adolescents in a drought-prone region in Kenya. Environment and Development Economics 26, 466-487. https://doi.org/10.1017/S1355770X20000406 